\title{
CNS Depressant and Analgesic Activities of Thysanolaena maxima Roxb. Available in Bangladesh
}

\section{Nazia Hoque ${ }^{1}$, Nusrat Fatemee ${ }^{1}$, Md. J unayet Hossain ${ }^{1}$, Meena Afroze Shanta ${ }^{1}$, and Muhammad Asaduzzaman ${ }^{2}$}

\author{
${ }^{1}$ Department of Pharmacy, East West University, Aftabnagar, Dhaka-1212, Bangladesh \\ ${ }^{2}$ Department of Clinical Pharmacy and Pharmacology, University of Dhaka, Dhaka-1000, Bangladesh
}

(Received: October 27, 2021; Accepted: December 18, 2021; Published (web): December 26, 2021)

\begin{abstract}
In Bangladesh, numerous tribal people of Chittagong Hill Tracts have been using different parts of Thysanolaena maxima Roxb. for many years. The present study was designed to investigate CNS depressant and analgesic activities of methanol extract of the aerial parts of the plant in mice models. CNS depressant activity of the crude extract (200 and $400 \mathrm{mg} / \mathrm{kg}$ ) was evaluated using open field, hole cross and thiopental-induced sleeping time tests using diazepam as the standard. Analgesic activity was determined using acetic acid-induced writhing and hot plate tests using diclofenac sodium as the standard. The extract showed dose dependent suppression of locomotion in open field and hole cross tests and exerted sedative action in thiopental induced sleeping time. In the open field and the hole-cross tests, maximum CNS depressant activity was observed at $90 \mathrm{~min}$ after administration of extract and the standard drug. The extract significantly induced the onset of sleep and prolonged the sleeping time in thiopental induced sleeping test compared to the control group. The extract produced significant $(\mathrm{p}<0.05)$ analgesic activity by inhibiting writhing by $41.89 \%$ and $60.81 \%$, at doses of 200 and $400 \mathrm{mg} / \mathrm{kg}$ body weight, respectively, which was comparable to the inhibition of diclofenac sodium (73.64\%). Additionally, in hot plate test, the extract exhibited a significant $(\mathrm{p}<0.05)$ increase in pain threshold in a dose dependent manner. The findings of the study are encouraging and demands further investigation of other bioactivities with isolation of pure compounds.
\end{abstract}

Key words: Thysanolaena maxima, CNS depressant, analgesic, sedative, diazepam

\section{INTRODUCTION}

Psychiatric disorders like anxiety and insomnia are the most common clinical problems across the world with severe health implications. Currently available treatment options for these disorders mostly aim to provide with symptomatic relief only. But continuous usages of these medications impose serious health problems including digestive and respiratory disturbances, cognitive impairment, physical dependence, tolerance etc. ${ }^{1,2}$ Pain is an unpleasant sensation triggered by both external and internal stimuli. ${ }^{3}$ Despite the availability of a wide varieties of clinically useful non-steroidal antiinflammatory drugs (NSAIDs) and opiates in market,

Correspondence to: Nazia Hoque

Email: nzh@ewubd.edu

Dhaka Univ. J. Pharm. Sci. 20(2): 227-233, 2021 (December)

DOI: https://doi.org/10.3329/dujps.v20i2.57173 none of these are free from side effects. ${ }^{4}$ These adverse events not only limit the therapeutic benefits but also necessitate the development of new therapeutic agents with minimal side effects along with maximum therapeutic outcomes. In an attempt to find the safest and cost-effective therapeutic options, scientists around the world are now focusing on medicinal plants. It is now scientifically evident that, in addition to these aforementioned benefits, nature is a rich source of structurally divergent compounds having beneficial effects on multiple diseases. ${ }^{5}$

The tall, tufted perennial grass Thysanolaena maxima Roxb. (Family: Poaceae; local name: Phul Jharu) is a medicinal plant native to South and East Asian countries like Bangladesh, Nepal, Thailand, India, China and Malaysia. Traditionally, roots, 
stems, flowers, leaves and whole plant of T. maxima have been used in the treatment of boils, tuberculosis, eye infection and stomach indigestion by various tribal traditional healers of Bangladesh and India. ${ }^{6,7}$ It has also been used as anthelmintic, antiemetic and tonic, to treat boils in some areas of Nepal, India and Thailand. ${ }^{8}$ Furthermore, literature studies have shown that $T$. maxima possessed antibacterial, antioxidant, chemopreventive and hepatoprotective activities. ${ }^{10,11}$ A study in Nepal demonstrated the isolation of a new compound, amrisoside from the floral part of $T$. maxima along with 35 known compounds including luteolin, $7 \alpha$-hydroxysitosterol, isoswertisin, isoquercetin, ergosterol peroxide, $\beta$ sitosterol, $7 \alpha$-hydroxysitosterol, adenosine, uridine, tryptophan, benzoic acid, syringic acid, erigeside $\mathrm{C}$, leonuriside A etc. ${ }^{12}$ These previous findings led us to evaluate the bioactivities of the different solvent extracts of $T$. maxima which proved the plant as a strong source of antioxidants. ${ }^{13}$ Later, five pure compounds, of which, two were sterols and three were phenols, were isolated from this plant which showed potential cytotoxicity against Vero cell lines. ${ }^{14}$ As a part of our ongoing research on Bangladeshi medicinal plants ${ }^{13-18}$, evaluation of the CNS depressant and analgesic activities of T. maxima were attempted.

\section{MATERIALS AND METHODS}

Chemicals and drugs. Diazepam and diclofenac sodium were procured from Square Pharmaceuticals Ltd., nalbuphine and thiopental sodium were purchased from Incepta Pharmaceuticals Ltd. and ACI Limited, respectively. Methanol and acetic acid were purchased from Merck, Germany and normal saline was provided by Opso Saline Ltd.

Plant collection and identification. The aerial part of the plant was collected from Pablakhali, Chittagong Hill Tracts, Bangladesh on August 20, 2014. The plant was identified by an expert of Bangladesh National Herbarium (BNH), Mirpur, Dhaka where a voucher specimen (DACB 42267) has been deposited. The fresh plant was washed thoroughly to remove surface dirt particles, sliced and shed dried for seven days. The dried plant materials were ground to coarse powder and stored in an air tight container.

Preparation of the plant extract. In brief, $900 \mathrm{~g}$ plant powder was submerged into adequate amount of methanol in an air-tight container for five days with intermittent shaking. The extract was filtered with cotton followed by Whatman number 1 filter paper. A deep brownish gummy extract was obtained after evaporating the filtrate with a rotary evaporator at low temperature $\left(45^{\circ} \mathrm{C}-50^{\circ} \mathrm{C}\right)$. The crude extract $(16 \mathrm{~g})$ was kept at $4^{\circ} \mathrm{C}$ for further analyses.

Experimental animals. Swiss albino mice (20$25 \mathrm{~g}$ in weight, 3-4 weeks of age, both male and female) were collected from International Center for Diarrheal Disease and Research, Bangladesh (icddr,b). Animals were kept under suitable environmental conditions where temperature was $25.0 \pm 1.0^{\circ} \mathrm{C}$ and a cycle of $12 \mathrm{hrs}$ light followed by $12 \mathrm{hrs}$ dark was maintained. The animals were befitted to the new environment of the laboratory for seven days with sufficient food and water. 'Ethical Principles and Guidelines of Scientific Experiments on Animals' (1995) provided by the 'Swiss Academy of Medical Sciences' and the 'Swiss Academy of Sciences' were followed for the care and treatment of the animals. Standard experimental protocols were followed to perform animal experimentations.

Open field test. Locomotor activity and exploratory action of a sample can be measured using open field method in mice. ${ }^{19}$ The animals were divided into control (received $0.005 \% \mathrm{v} / \mathrm{v}$ carboxymethyl cellulose in normal saline), positive control (received diazepam $1 \mathrm{mg} / \mathrm{kg}$ body weight) and two test groups (received 200 and $400 \mathrm{mg} / \mathrm{kg}$ body weight of extract) containing five mice each. The apparatus used in this experiment was an open field containing white and black colored squares alternatively. The apparatus was encircled by a wall which was $40 \mathrm{~cm}$ in height. The number of squares crossed by the mice after oral administration of particular treatments, were counted at $0,30,60,90$ and $120 \mathrm{~min}$ for $3 \mathrm{~min}$ period of time. 
Hole cross test. A wooden box having a partition wall $(7.5 \mathrm{~cm}$ height $)$ with a hole $(3 \mathrm{~cm}$ diameter) in the middle was used for this test. The dimensions of the box were $30 \mathrm{~cm} \times 20 \mathrm{~cm} \times 14 \mathrm{~cm}$. After oral administration of particular treatments described above, mice were placed on one side of the partition wall inside the box. Each mouse crossed the hole for several times and moved from one chamber to another. The number of movements for each animal was observed for 3 min at $0,30,60,90$ and 120 min. $^{20}$

Thiopental sodium-induced sleeping time. The control group of mice was treated with vehicle ( $0.005 \% \mathrm{CMC}$ in water), positive control group with diazepam (1 $\mathrm{mg} / \mathrm{kg}$ body weight) and test groups were treated with the extract of T. maxima (200 and $400 \mathrm{mg} / \mathrm{kg}$ body weight). Twenty minutes later, a dose of thiopental sodium $(40 \mathrm{mg} / \mathrm{kg})$ was injected via intraperitoneal route to each animal for sleep induction. The time between administration of thiopental sodium to loss of righting reflex was counted as onset of action of the drug. The time between the loss of reflex followed by recovery was also counted as the duration of sleep. ${ }^{21}$

Acetic acid-induced writhing test. The animals were split into four groups with five mice where control group received vehicle $(0.005 \% \mathrm{v} / \mathrm{v} \mathrm{CMC}$ in normal saline), positive control group received diclofenac sodium $(1 \mathrm{mg} / \mathrm{kg})$ and test groups received methanol extract of T. maxima (200 and $400 \mathrm{mg} / \mathrm{kg}$ body weight). Acetic acid solution $(0.7 \% \mathrm{v} / \mathrm{v})$ was injected via intraperitoneal route to each animal (0.1 $\mathrm{ml} / 10 \mathrm{~g}$ body weight) after $15 \mathrm{~min}$ of intraperitoneal administration of diclofenac sodium and $30 \mathrm{~min}$ of oral administration of vehicle and crude extract. The mice were noticed for specific body stretching known as 'writhing' ${ }^{22}$ for the next $20 \mathrm{~min}$.

Hot plate method. The animals were treated as mentioned above except animals of positive control group (received nalbuphine at $10 \mathrm{mg} / \mathrm{kg}$ body weight). Eddy's hot plate maintaining temperature of $52 \pm 0.5^{\circ} \mathrm{C}$ was used as the hot plate for this experiment. Each animal was placed on the hot plate and their response was recorded at $0,30,60$ and 90 min following oral administration of the samples. ${ }^{23}$ Forepaw licking, jumping from the hot plate or withdrawal of the paws was counted as their response.

Statistical analysis. One-way ANOVA followed by Dunnet's test was used for the statistical analysis of animal experiments. The results were compared with the control group, $\mathrm{p}<0.05$ were considered to be statistically significant.

\section{RESULTS AND DISCUSSION}

Open field test. The extract of $T$. maxima significantly $(\mathrm{p}<0.05-0.001)$ reduced the locomotion at 200 and $400 \mathrm{mg} / \mathrm{kg}$ body weight doses. The extract significantly decreased the movements of the mice throughout the observation period (Table 1).

Table 1. Effects of the methanol extract of T. maxima on open field test.

\begin{tabular}{|c|c|c|c|c|c|c|c|}
\hline \multirow[t]{2}{*}{ Groups } & \multirow[t]{2}{*}{ Treatments } & \multirow[t]{2}{*}{ Dose } & \multicolumn{5}{|c|}{ Number of square crossed } \\
\hline & & & $0 \min$ & $30 \mathrm{~min}$ & $60 \mathrm{~min}$ & $90 \mathrm{~min}$ & $120 \mathrm{~min}$ \\
\hline Control & $\begin{array}{l}0.005 \% \mathrm{w} / \mathrm{v} \mathrm{CMC} \\
\text { in normal saline }\end{array}$ & $10 \mathrm{ml} / \mathrm{kg}$ & $113.2 \pm 3.83$ & $118.2 \pm 2.66$ & $120.8 \pm 3.58$ & $121.4 \pm 3.58$ & $119.4 \pm 2.48$ \\
\hline Standard & Diazepam & $1 \mathrm{mg} / \mathrm{kg}$ & $109.4 \pm 4.96$ & $76 \pm 7.93^{*}$ & $58.2 \pm 4.16^{* * *}$ & $33.2 \pm 5.2^{* * * *}$ & $16.8 \pm 3.56^{* * *}$ \\
\hline \multirow{2}{*}{$\begin{array}{l}\text { Test } \\
\text { sample }\end{array}$} & METM & $200 \mathrm{mg} / \mathrm{kg}$ & $116.8 \pm 4.09$ & $93.2 \pm 8.09^{*}$ & $74 \pm 8.09^{* * *}$ & $36 \pm 2.95^{* * *}$ & $19 \pm 2.53^{* * *}$ \\
\hline & & $400 \mathrm{mg} / \mathrm{kg}$ & $117.2 \pm 4.88$ & $84.2 \pm 5.26^{*}$ & $66.6 \pm 6.84^{* * *}$ & $35 \pm 4.89^{* * * *}$ & $17.6 \pm 3.09^{* * *}$ \\
\hline
\end{tabular}

Values are mean \pm SEM, $(\mathrm{n}=5) ;{ }^{*} \mathrm{p}<0.05$ and ${ }^{* * *} \mathrm{p}<0.001$ were considered significant (One way ANOVA followed by Dunnett's test); METM: Methanol extract of T. maxima.

Hole cross test. Methanol extract of T. maxima showed significant reduction of movement $(\mathrm{p}<0.01-$
0.001 ) at the doses of 200 and $400 \mathrm{mg} / \mathrm{kg}$ body weight compared to the standard diazepam. The 
number of hole crossed by mice from one chamber to another was decreased in a dose dependent manner. The maximum CNS depressant effect was observed at $120 \mathrm{~min}$ (Figure 1).

Thiopental sodium-induced sleeping time. In this test, the plant extract at doses of 200 and 400 $\mathrm{mg} / \mathrm{kg}$ body weight reduced the onset of sleep and increased the duration of the sleeping time compared to the standard diazepam (Table 2). The extract showed a statistically significant $(\mathrm{p}<0.01-0.001)$ dose dependent activity.

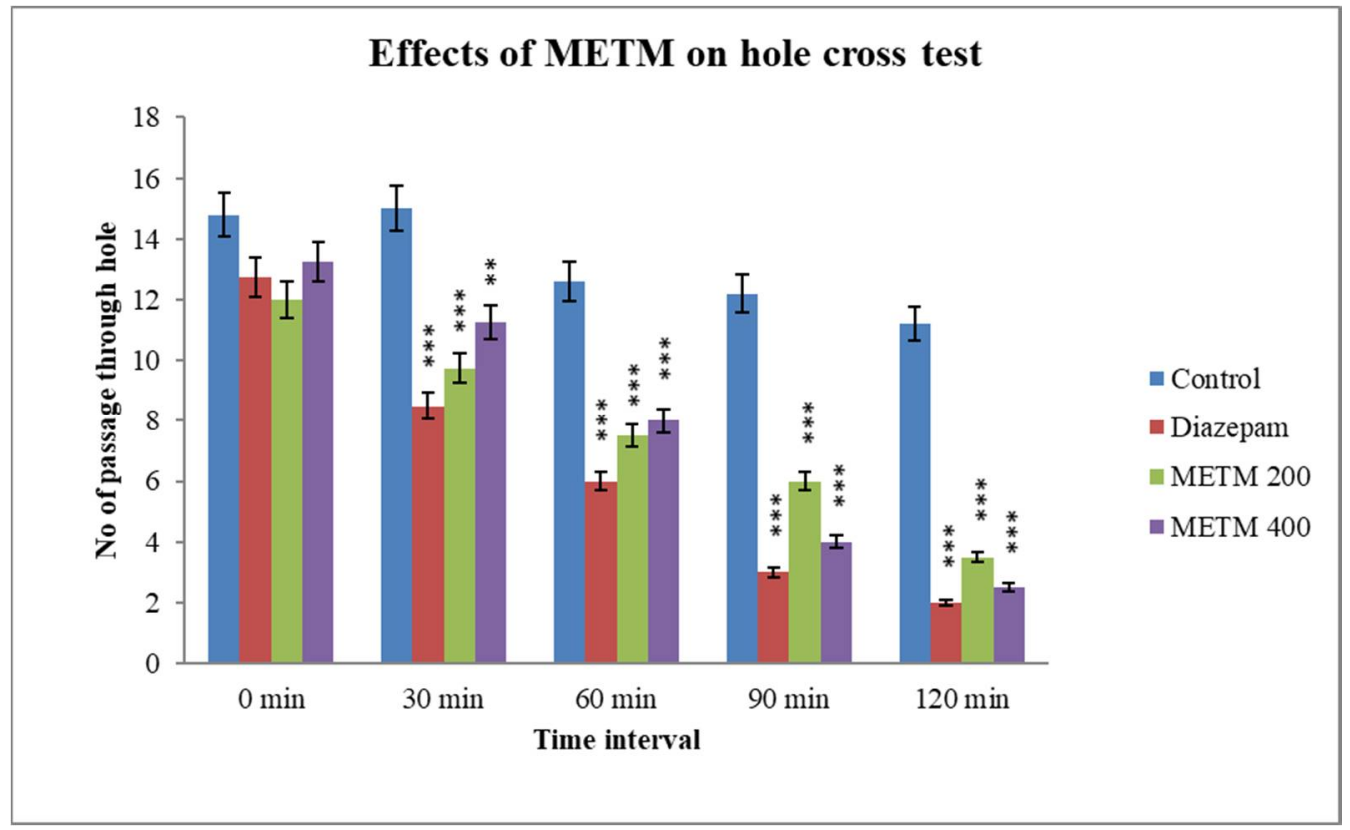

Figure 1. Effects of the methanol extract of T. maxima in hole cross test. Values are mean \pm SEM, $(\mathrm{n}=5)$; and $* * p<0.01$ and $* * * p<0.001$ were considered significant (One way ANOVA followed by Dunnett's test); METM: Methanol extract of T. maxima.

Table 2. Effects of methanol extract of T. maxima on thiopental sodium-induced sleeping test.

\begin{tabular}{lllll}
\hline Groups & Treatments & Dose & Onset of sleep (min) & Duration of sleep (min) \\
\hline Control & $\begin{array}{l}\text { 0.005\% w/v CMC in } \\
\text { normal saline }\end{array}$ & $10 \mathrm{ml} / \mathrm{kg}$ & $26.2 \pm 1.39$ & $107.6 \pm 1.98$ \\
Standard & Diazepam & $1 \mathrm{mg} / \mathrm{kg}$ & $15 \pm 0.71^{* * *}$ & $164.8 \pm 5.05^{* * *}$ \\
Test sample & METM & $200 \mathrm{mg} / \mathrm{kg}$ & $19.6 \pm 1.16^{* *}$ & $137.4 \pm 3.47^{* * *}$ \\
& & $400 \mathrm{mg} / \mathrm{kg}$ & $17.8 \pm 0.86^{* * *}$ & $153.2 \pm 2.15^{* * *}$ \\
\hline
\end{tabular}

Values are mean \pm SEM, $(\mathrm{n}=5) ; * \mathrm{p}<0.01$ and ${ }^{* * *} \mathrm{p}<0.001$ were considered significant (One way ANOVA followed by Dunnett's test); METM: Methanol extract of T. maxima.

Acetic acid-induced writhing test. In acetic acid-induced writhing test, methanol extract of $T$. maxima significantly $(\mathrm{p}<0.01-0.001)$ suppressed acetic acid induced writhing in mice at both doses (200 and $400 \mathrm{mg} / \mathrm{kg}$ body weight). At $400 \mathrm{mg} / \mathrm{kg}$ dose, the plant extract showed maximum inhibition (60.81\%). The standard diclofenac sodium inhibited the writhing by $73.64 \%$ (Table 3 ).
Hot plate method. The methanol extract of $T$. maxima increased the latency time in hot plate dose dependently and significantly ( $\mathrm{p}<0.05)$ as presented in figure 2. At the dose of $400 \mathrm{mg} / \mathrm{kg}$ body weight, METM produced highest analgesia at the $4^{\text {th }}$ observation period (90 min) of time. 
Table 3. Effects of methanol extract of T. maxima on acetic acid-induced writhing in mice.

\begin{tabular}{lllll}
\hline Groups & Treatments & Dose & No of writhings & Percent inhibition \\
\hline Control & $0.005 \%$ w/v CMC in normal saline & $10 \mathrm{ml} / \mathrm{kg}$ & $29.6 \pm 4.56$ & - \\
Standard & Diclofenac-Na & $1 \mathrm{mg} / \mathrm{kg}$ & $7.8 \pm 3.70^{* * *}$ & $73.64 \%$ \\
Test sample & METM & $200 \mathrm{mg} / \mathrm{kg}$ & $17.2 \pm 5.12^{* *}$ & $41.89 \%$ \\
& & $400 \mathrm{mg} / \mathrm{kg}$ & $11.6 \pm 3.78^{* * *}$ & $60.81 \%$ \\
\hline
\end{tabular}

Values are mean \pm SEM, $(\mathrm{n}=5) ; * * \mathrm{p}<0.01$ and $* * * \mathrm{p}<0.001$ were considered significant (One way ANOVA followed by Dunnett's test); METM: Methanol extract of T. maxima.

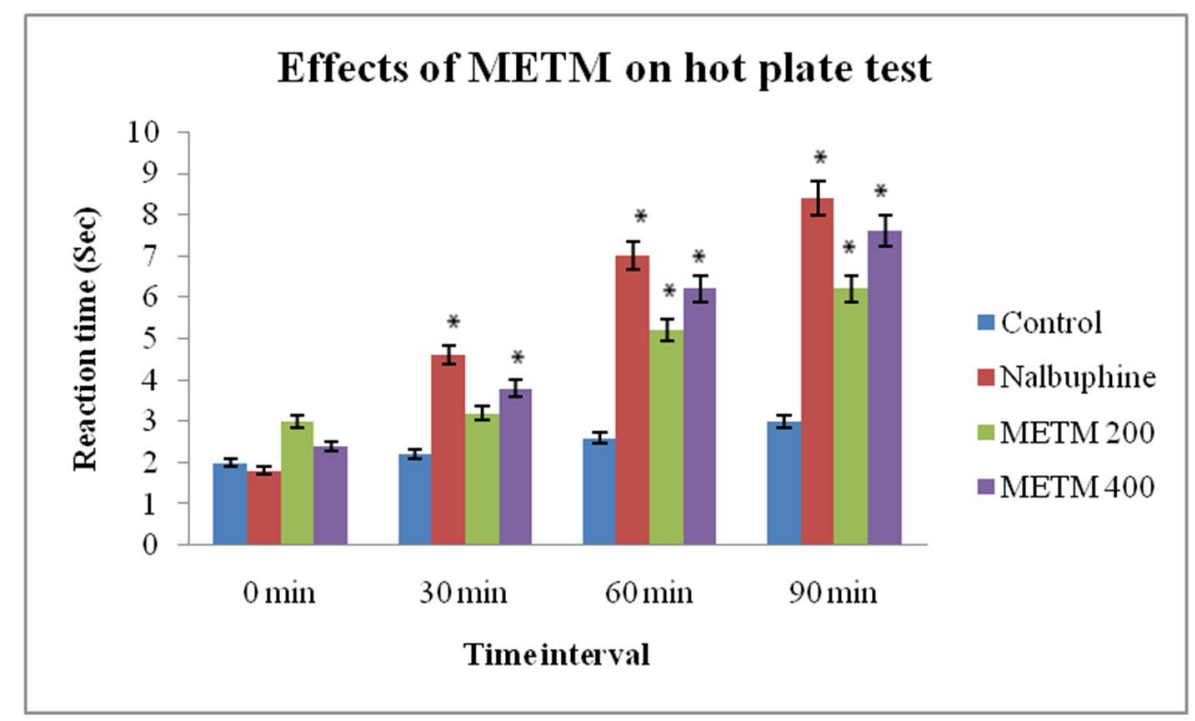

Figure 2. Effects of methanol extract of T. maxima on latency to hotplate test. Values are mean \pm SEM, $(n=5)$; * $<0.05$ was considered significant (One way ANOVA followed by Dunnett's test); METM: Methanol extract of T. maxima.

The major inhibitory neurotransmitter of central nervous system (CNS) known as gamma amino butyric acid (GABA) has a role to play in the diseases like depression, Parkinson's disease, epilepsy etc. ${ }^{24}$ On the other hand, diazepam is a very popular drug used to treat sleep disorder which acts via opening of the chloride channel and causing allosteric change in GABA receptors to induce GABA-mediated postsynaptic inhibition. ${ }^{25}$ Due to the ability of diazepam to calm down the neuronal activity, it can be used as standard in different neuropharmacological experimental models. $^{26}$ Locomotor activity is considered as a measurement of the level of excitability of the CNS and it is an index of alertness which indicates CNS depressant activity. ${ }^{27}$ In this study, METM in both doses produced significant reduction of locomotion indicative of its CNS depressant potential in both open field and hole cross test. But in both experiments, maximum inhibition was observed for $400 \mathrm{mg} / \mathrm{kg}$ body weight dose of the plant extract. Another classical model to evaluate CNS depressant activity is thiopental sodium induced sleeping test where thiopental exerts its effect by enhancing the inhibitory action of the GABA receptor. ${ }^{26}$ The result showed significant reduction in the time required to induce sleep and also increased the duration of the sleep, indicating sedative potential of the extract. It is scientifically evident that flavonoids and steroids can act as ligands for GABA type A (GABAA) receptors in CNS. Moreover, it was also reported that triterpenoids and saponins can exert agonistic action at GABAA receptor complex. ${ }^{2,5,28}$ Our previous studies found strong presence of several phyto- 
constituents such as flavonoids, terpenoids, glycosides and saponins in aerial part of T. maxima available in Bangladesh. ${ }^{13}$ These phytoconstituents may play a vital role in the CNS depressant activity of the extract though further studies are required before any conclusion is made.

The analgesic potential of METM was investigated using chemical (acetic acid) and thermal (hot plate) methods. Acetic acid induced writhing test assesses peripheral analgesic activity of compounds like non-steroidal anti-inflammatory agents and steroids, which exert their effects by alteration of peritoneal mast cells, acid sensing ion channels and the prostaglandin pathways. $^{29}$ Acetic acid causes abdominal distortion and pain by releasing several inflammatory mediators such as histamine, cytokines and arachidonic acid metabolites which is produced during cyclooxygenase and prostaglandin biosynthesis. ${ }^{19}$ The results of our present study indicated that the extract is capable of suppressing acetic acid induced-writhing and producing significant analgesia probably by inhibiting the local inflammatory response mentioned above. ${ }^{20}$

The hotplate method is used to evaluate the antinociceptive activity of organic compounds that act through opioid receptors of the central and peripheral nervous system. ${ }^{30}$ Natural or synthetic opioid drugs act in both the central and peripheral nervous systems and can produce strong analgesia. ${ }^{31}$ Methanol extract of $T$. maxima showed antinociceptive activity by increasing latency time in hot plate test in comparison with the vehicle in a dose dependent manner. Maximum analgesic effect was found at 90 min following treatment with test sample and the standard. The results obtained from acetic acid writhing and hot plate method showed that the extract (200 and $400 \mathrm{mg} / \mathrm{kg}$ ) could exhibit its antinociceptive activity by inhibiting both peripheral and central mechanisms of pain through opioid receptor, which is similar to the action of narcotic analgesics. Moreover, it is evident from the literature that flavonoids and tannins have prominent antinociceptive activity. ${ }^{32,33}$ Presence of phenolic compounds, flavonoids and $\operatorname{tannin}^{13,14}$ in the plant might be responsible for the antinociceptic property of the extract though further investigation is required to confirm this.

\section{CONCLUSION}

In light of the findings of the present study, it can be concluded that the methanol extract of Thysanolaena maxima possesses remarkable analgesic and CNS effect. The plant could be a potent source of bioactive compounds which could be used as lead in discovery of CNS depressant and analgesic drug molecules. Isolation of bioactive compounds from this plant is under investigation and will be reported in due course of time.

\section{ACKNOWLEDGEMENT}

The authors are thankful to the Department of Pharmacy, East West University, Dhaka, Bangladesh for providing all the technical and financial supports to conduct the research.

\section{REFERENCES}

1. Moniruzzaman, M., Rahman, A. and Ferdous, A. 2015. Evaluation of sedative and hypnotic activity of ethanolic extract of Scoparia dulcis Linn. Evid. Based Complement. Alternat. Med. 2015, 873954.

2. Khatoon, M.M., Khatun, M.H., Islam, M.E. and Parvin, M.S. 2014. Analgesic, antibacterial and central nervous system depressant activities of Albizia procera leaves. Asian Pac. J. Trop. Biomed. 4, 279-284.

3. Garland, E. L. 2012. Pain processing in the human nervous system: a selective review of nociceptive and biobehavioral pathways. Prim. Care. 39, 561-571.

4. Shojaii, A., Motaghinejad, M., Norouzi, S. and Motevalian, M. 2015. Evaluation of anti-inflammatory and analgesic activity of the extract and fractions of Astragalus hamosus in animal models. Iran. J. Pharm. Sci. 14, 263-269.

5. Sultana, T., Mannan, M.A. and Ahmed, T. 2018. Evaluation of central nervous system (CNS) depressant activity of methanolic extract of Commelina diffusa Burm. in mice. Clin. Phytoscience. 4, 1-7.

6. Hynniewta, S.R. and Kumar, Y. 2008. Herbal remedies among the Khasi traditional healers and village folks in Meghalaya. Indian J. Tradit. Knowl. 7, 581-586.

7. Rout, J., Sajem, A.L. and Nath, M. 2012. Medicinal plants of North Cachar Hills district of Assam used by the Dimasa tribe. Indian J. Tradit. Knowl. 11, 520-527.

8. Hasan, M.K., Gatto, P. and Jha, P.K. 2013. Traditional uses of wild medicinal plants and their management practices in Nepal- a study in Makawanpur district. Int. J. Med. Aromat. Plants. 3, 102-112. 
9. Rahmatullah, M., Ayman, U., Akter, F., Sarker, M., Sifa, R., Sarker, B., Chyti, H.N., Jahan, F.I., Chowdhury, M.H. and Chowdhury, S.A. 2013. Medicinal formulations of a Kanda tribal healer- a tribe on the verge of disappearance in Bangladesh. Afr. J. Tradit. Complement. Altern. Med. 10, 213-222.

10. Subba, B. and Basnet, P. 2014. Antimicrobial and antioxidant activity of some indigenous plants of Nepal. J. Pharmacogn. Phytochem. 3, 62-67.

11. Gnanaraj, C., Haque, A.T.M.E. and Iqbal, M. 2012. The chemopreventive effects of Thysanolaena latifolia against carbon tetrachloride (CCl4)-induced oxidative stress in rats. J. Exp. Integr. Med. 2, 345-355.

12. Shrestha, S., Park, J.H., Cho, J.G., Lee, D.Y., Jeong, R.H., Song, M.C., Cho, S.K., Lee, D.S. and Baek, N.I. 2016. Phytochemical constituents from the florets of tiger grass Thysanolaena latifolia from Nepal. J. Asian Nat. Prod. Res. 18, 206-213.

13. Hoque, N., Sohrab, M.H., Debnath, T. and Rana, M.S. 2016. Antioxidant, antibacterial and cytotoxic activities of various extracts of Thysanolaena maxima (Roxb.) Kuntze available in Chittagong Hill Tracts of Bangladesh. Int. J. Pharm. Pharm. Sci. 8, 168-172.

14. Hoque, N., Sohrab, M.H., Afroz, F., Rony, S.R., Sharmin, S., Moni, F., Hasan, C.M. and Rana, M.S. 2020. Cytotoxic metabolites from Thysanolaena maxima Roxb. available in Bangladesh. Clin. Phytoscience. 6, 1-10.

15. Shanta, M.A., Mondal, M., Majumder, S., Islam, I., Hoque, N., Tithi, N.S. and Rana, M.S. 2018. Pharmacological investigations of chloroform extract of Stereospermum chelonoides leaves. Int. J. Pharm. Sci. 9, 4256-4266.

16. Hoque, N., Rahman, S., Jahan, I., Shanta, M.A., Tithi, N.S. and Nasrin, N. 2018. A comparative phytochemical and biological study between different solvent extracts of Bombax ceiba roots available in Bangladesh. Pharmacol. Pharm. 9, 53-66.

17. Islam, M.I., Shanta, M.A., Mondal, M., Hoque, N., Majumder, S., Ahmed, T. and Rana, M.S. 2018. Protective effect of chloroform extract of Stereospermum chelonoides bark against amyloid beta42 induced cell death in SH-SY5Y cells and against inflammation in Swiss albino mice. J. Basic Clin. Physiol. Pharmacol. 29, 621-630.

18. Ghosh, R., Hoque, N., Shanta, M.A., Nasrin, N. and Asaduzzaman, M. 2020. Antioxidant, antimicrobial and cytotoxic activities of different fractions of Citrus aurantifolia peel. Dhaka Univ. J. Pharm. Sci. 19, 161-168.

19. Shajib, M., Akter, S., Ahmed, T. and Imam, M.Z. 2015. Antinociceptive and neuropharmacological activities of methanol extract of Phoenix sylvestris fruit pulp. Front. Pharmacol. 6, 212.

20. Uddin, M., Ali Reza, A.S.M., Abdullah-Al-Mamun, M., Kabir, M.S., Nasrin, M., Akhter, S., Arman, M., Islam, S. and Rahman, M. 2018. Antinociceptive and anxiolytic and sedative effects of methanol extract of Anisomeles indica: an experimental assessment in mice and computer aided models. Front. Pharmacol. 9, 246.
21. Ali, M.S., Dash, P.R. and Nasrin, M. 2015. Study of sedative activity of different extracts of Kaempferia galanga in Swiss albino mice. BMC Complement. Altern. Med. 15, 158.

22. Zulfiker, A.H.M., Rahman, M.M., Hossain, M.K., Hamid, K., Mazumder, M.E.H. and Rana, M.S. 2010. In vivo analgesic activity of ethanolic extracts of two medicinal plantsScoparia dulcis L. and Ficus racemosa Linn. Biol. Med. 2, 42-48.

23. Heidari, M.R., Azad, E.M. and Mehrabani, M. 2006. Evaluation of the analgesic effect of Echium amoenum Fisch $\&$ CA Mey. extract in mice: possible mechanism involved. $J$. Ethnopharmacol. 103, 345-349.

24. Kumar, K., Sharma, S., Kumar, P. and Deshmukh, R. 2013. Therapeutic potential of GABAB receptor ligands in drug addiction, anxiety, depression and other CNS disorders. Pharmacol. Biochem. Behav. 110, 174-184.

25. Bhosale, U.A., Yegnanarayan, R., Pophale, P.D., Zambare, M.R. and Somani, R.S. 2011. Study of central nervous system depressant and behavioral activity of an ethanol extract of Achyranthes aspera (Agadha) in different animal models. Int. J. Appl. Basic Med. Res. 1, 104-108.

26. Huang, F., Xiong, Y., Xu, L., Ma, S. and Dou, C. 2007. Sedative and hypnotic activities of the ethanol fraction from Fructus schisandrae in mice and rats. $J$. Ethnopharmacol. 110, 471-475.

27. Dey, P., Chandra, S., Chatterjee, P. and Bhattacharya, S. 2011. Neuropharmacological properties of Mikania scandens (L.) Willd. (Asteraceae). J. Adv. Pharm. Technol. Res. 2, 255-259.

28. Akter, R., Hasan, S.R., Hossain, M.M., Jamila, M., Mazumder, M.E.H., Rana, M.S. and Rahman, S. 2010. Analgesic and neuropharmacological effects of Xanthium indicum leaves. Lat. Am. J. Pharm. 29, 520-525.

29. Franzotti, E.M., Santos, C.V.F., Rodrigues, H.M.S.L., Mourao, R.H.V., Andrade, M.R. and Antoniolli, A.R. 2000. Anti-inflammatory, analgesic activity and acute toxicity of Sida cordifolia L. (Malva-branca). J. Ethnopharmacol. 72, 273-277.

30. Pathan, H. and Williams, J. 2012. Basic opioid pharmacology: an update. Br. J. Pain. 6, 11-16.

31. Pal, S., Sen, T. and Chaudhuri, A.K. 1999. Neuropsychopharmacological profile of the methanolic fraction of Bryophyllum pinnatum leaf extract. J. Pharm. Pharmacol. 51, 313-318.

32. Narayana, K.R., Reddy, M.S., Chaluvadi, M.R. and Krishna, D.R. 2001. Bioflavonoids classification, pharmacological, biochemical effects and therapeutic potential. Indian $J$. Pharmacol. 33, 2-16.

33. Ramprasath, V.R., Shanthi, P. and Sachdanandam, P. 2006. Immunomodulatory and anti-inflammatory effects of Semecarpus anacardium LINN. nut milk extract in experimental inflammatory conditions. Biol. Pharm. Bull. 29, 693-700. 